\title{
Influencia del rediseño de los procesos productivos de una empresa de envolturas flexibles basado en la mejora continua
}

Andrea Lizzeth Aldea Molina ${ }^{1}$

Recibido: 12/12/2021 AcEPtado: 13/04/2021 Publicado: 26/07/2021

\begin{abstract}
RESUMEN
La empresa en estudio pretendía disminuir los índices de scrap de cada proceso de la producción de envolturas flexibles, originados como resultado de malos procedimientos, devoluciones internas, bobinas y/o fardos observados. Asimismo, se esperaba una reducción de reclamos como resultado de la mejora en la calidad del producto terminado. Al reducir el scrap en cada proceso de la división de plásticos, se observó una disminución en los reprocesos y costos, lo que a su vez tuvo un impacto positivo en los ingresos de la empresa, dado que al brindar un producto con altos estándares de calidad se fidelizó a los clientes. Además, se mejoró la eficiencia de los procesos de las áreas de extrusión, impresión, corte, laminado y sellado. Al poseer procedimientos y procesos estandarizados, se mejoró el tiempo de ejecución de los mismos, lo que originó una mejor imagen antes los clientes y competidores.
\end{abstract}

Palabras clave: procedimientos; reproceso; cliente; reclamo.

\section{INTRODUCCIÓN}

La presente investigación tiene como propósito servir de base para investigaciones de vanguardia, académicas o de utilidad social que beneficien a:

- Investigadores, estudiantes y personas que se encuentren interesados en la mejora continua de procesos, pues se destacan los aspectos más relevantes.

- Accionistas y colaboradores de la empresa, pues se obtienen mejores márgenes de utilidad.

- Clientes, pues se observa un bajo índice de producto no conforme.

- Competidores, pues se recomiendan mejoras para la disminución del scrap.

Este artículo busca ser un instrumento de evaluación que aporte conocimiento sobre los factores que influyen en la generación del scrap y sus consecuencias, así como sobre el patrón de comportamiento que presentan dichos factores. Este trabajo es una propuesta de investigación para todas las partes interesadas en la obtención de procesos eficientes que generen bajos índices de scrap.

Asimismo, la presente investigación da a conocer el rediseño de los procesos basado en la mejora continua, por medio de la evaluación y ejecución de:

- Plan de autocontrol en la producción

- Análisis de causa-raíz del producto no conforme

- Establecimiento de acciones correctivas

Se pretende conocer además cómo, mediante la elaboración del plan de autocontrol de la producción en cada proceso, se reducirán los índices de scrap generado en los procesos de la división de producción plásticos.

1 Ingeniera industrial por la Universidad Alas Peruanas. Actualmente, es consultora independiente. (Lima, Perú).

ORCID: https://orcid.org/0000-0002-0118-971X

Autor de correspondencia: alizaldeamolina@gmail.com 


\section{ANTECEDENTES}

Fernández y Ramírez (2017) presentaron un método de mejora apoyado en la gestión de procesos para ampliar la productividad, muy similar al que se desarrolla en la investigación propuesta en este documento.

Cáceres (2017) identificó que la implementación de la mejora continua optimiza los procesos del área en un almacén de productos electrónicos y, de este modo, eleva su productividad.

Gutiérrez y Vega (2019) elaboraron un plan de mejora en el área de producción para incrementar la productividad y concluyeron que la estandarización de procedimientos es elemental para la elaboración de un plan de mejora.

\section{Eficiencia}

Para De Asís (2007), la eficiencia es el uso óptimo de los recursos de manera que no se produzca el despilfarro de estos. Con la frase del autor se entiende que la eficiencia de una empresa, producto o persona depende de su capacidad para obtener resultados óptimos minimizando el impacto económico de los recursos. Por esto, es necesario que el gestor de la empresa conozca al detalle los procesos que intervienen en la organización; además, debe contar con planes estratégicos de mejora en cada área de la empresa.

\section{Mejora continua}

Chang (1996) proporciona una guía metódica que se utiliza para la obtención de importantes mejoras en los procesos que suministran productos y servicios a los clientes. Al recurrir a la mejora continua, se observan minuciosamente los procesos y se obtienen maneras de mejorarlos. Se busca que el resultado sea más rápido, que se perciba una mejora y que sea más eficiente o efectivo para producir un servicio o producto.

La mejora continua de los procesos es la creación de metodologías (procedimientos, monitoreos, mediciones de desempeño, etc.) que se centren en la exploración continua de los inconvenientes que aparecen en la organización; además, la mejora continua procura optimizar el producto o servicio que provee la organización, de modo que resulte en la satisfacción del cliente, reducción de costos y racionalización de recursos.

La Figura 1 ilustra de manera gráfica el concepto expuesto en el párrafo anterior.

\section{Producción}

D'Alessio (2004) menciona que la producción abarca el planteamiento, el diseño, la operación y el control de los sistemas que elaboran bienes y servicios. Esta comprende además un amplio rango de procesos productivos que generan valor añadido al producto o servicio. Por su parte, Everett y Ronald (1991) señalan que la producción involucra la transformación de insumos o materia prima de un producto. Los autores coinciden en que la producción está relacionada con la generación de mercancías o actividades que comprendan un conjunto de funciones, tangibles o intangibles, para la satisfacción del cliente. Además, subrayan

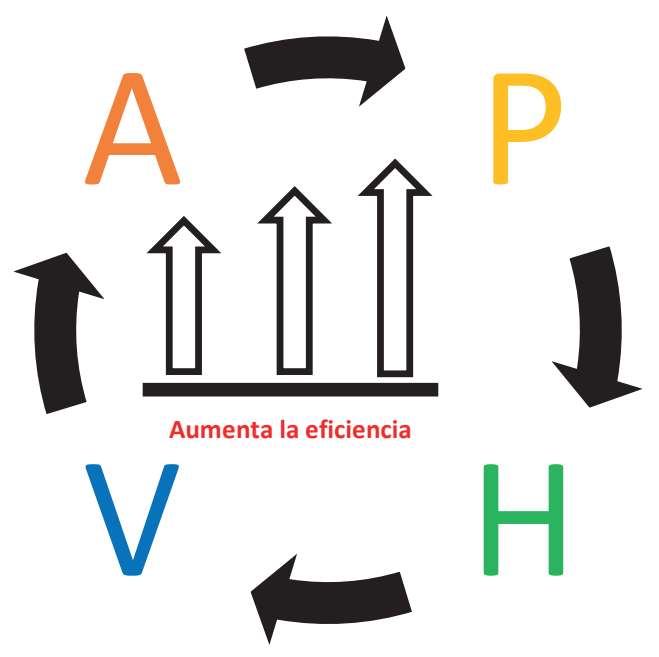

Figura 1. Esquema de mejora continua. Fuente: Elaboración propia. 
cómo se interconectan las fases de la producción para la obtención del bien o servicio.

Producción es el resultado de actividades donde se obtiene un bien o servicio y, con ese fin, cada proceso ejecutado adiciona un valor agregado.

\section{Procesos}

Martín y Martín (2013) indican que los procesos son el conjunto de actividades que manipulan las entradas y salidas. Tener mapeados, definidos y controlados los procesos permite conocer el trabajo desarrollado en la organización y, por tanto, da la oportunidad de seguir practicando la mejora continua. En el proceso hay ingresos y salidas. Los ingresos son los insumos o materias primas relevantes para la elaboración de las actividades que conforman el proceso; mientras que las salidas están conformadas por el producto y las mermas que se producen. Además, dan a conocer la importancia del control del proceso en la optimización de las actividades de la organización.

Para García (1998), el proceso se origina de una situación inicial conocida que se desea llevar a una situación final también conocida, pero en el transcurso se presentan una serie de barreras o impedimentos, que deben ser resueltos mediante la realización de operaciones. El autor destaca que entre el inicio y final del proceso surgen imprevistos que deben ser examinados y mitigados; es necesario identificar y conocer todas las actividades del proceso, pues solo así se determinarán los procedimientos necesarios para su inspección, para esto, es crucial que el analista conozca los procesos involucrados.

Alarcón (1998) menciona que un proceso es un grupo de actividades que, con el ingreso de insumos, crea un producto de valor para el cliente. Dichas actividades están relacionadas entre sí y finalizan con la entrega del producto o servicio.

En el párrafo anterior se recalca que las actividades que se realizan para la obtención de un producto o servicio deben estar estrechamente interconectadas y ser afines, de modo que puedan generar el valor agregado que debe contener cada etapa de su producción.

Por otro lado, Chiavenato y Sapiro (2011) manifiestan que los procesos son los medios que permiten obtener resultados. Son conjuntos de actividades que utilizan recursos para transformar materiales o materia prima en productos. Se debe considerar que la administración por procesos crea una dinámica de mejora continua para que las organizaciones obtengan ganancias significativas en términos de desempeño, eficiencia, eficacia y costo.

En el enunciado anterior se mencionan las salidas o resultados de los conjuntos de actividades; para obtener estos resultados se utilizan entradas. Además, menciona también el concepto de administración por procesos y cómo está orientado a generar una cultura de optimización de procesos para una mejor productividad organizacional.

Del mismo modo, Pérez (2010) señala que se trata de un conjunto de actividades congruentes entre ellas, que transforman los elementos de entrada en salidas con un valor agregado. Además, considera que los procesos son una secuencia ordenada de actividades repetitivas cuyo producto tiene valores importantes para los clientes. La Figura 2 ilustra este concepto.

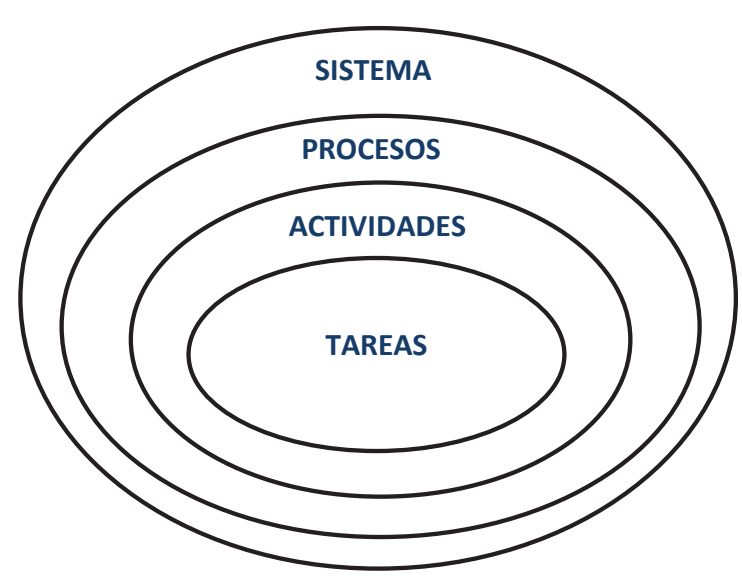

Figura 2. El conjunto detallado del sistema y procesos. Fuente: Pérez (2010), Gestión por Procesos p.52. 
Los procesos deben contar con una secuencia de tareas, las cuales tienen una interacción definida; además, el conjunto de tareas nos lleva a desempeñar las actividades necesarias para obtener un producto final con el valor requerido por el cliente.

\section{Rediseño de procesos}

Alarcón (1998) menciona que una comprensión elemental y profunda de los procesos que proporcionan valor agregado según los clientes es fundamental para conseguir un rediseño completo de los procesos e implementar una modificación notable de los mismos para obtener mejoras drásticas. De este modo se logra mejorar el rendimiento (costes, calidad, servicio, productividad, rapidez, etc.). Además, el propósito del trabajo y las estructuras del negocio varían al mismo tiempo, de tal manera que permiten determinar la idoneidad de la implementación de nuevas estrategias corporativas.

El rediseño del proceso solo puede concretarse si se conoce a fondo cada una de las actividades indispensables para la producción; decidirse por el cambio puede, aunque no necesariamente, implicar invertir grandes montos, pero a la larga los beneficios son mayores respecto a lo invertido.

El rediseño de procesos se explica de forma sencilla y gráfica en la Figura 3.

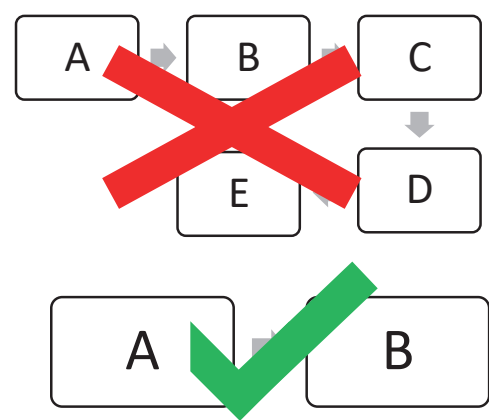

Figura 3. Definición de rediseño de procesos. Fuente: Elaboración propia.

\section{METODOLOGÍA}

El diseño de la investigación es de tipo cuasi-experimental de series temporales, ya que se desarrollan al paso de varias observaciones sobre una o más variables en el momento pretest y postest. A continuación, se presenta el esquema utilizado:

\section{$\mathrm{O} 1 \mathrm{O} 2 \mathrm{O} 3 \times 0405 \mathrm{O} 6$}

\section{En donde:}

O: son las observaciones realizadas en el momento pretest y postest.
X: es la implementación de la variable independiente.

El tipo de investigación presenta un enfoque cuantitativo y experimental porque se procederá a recolectar datos para la comprobación de la hipótesis, apoyándose en la medición de las variables y en la manipulación de una variable independiente.

Las unidades de análisis son las órdenes de producción (OP) generadas en la empresa en estudio y los reportes estadísticos obtenidos de la data histórica, considerando como pretest el año 2014 y el postest el año 2019 para cada uno de los procesos.

Se debe considerar que se realizó el rediseño de los procesos basado en la mejora continua, mediante la evaluación y ejecución de:

- Análisis de causa-raíz del producto no conforme

Se definieron las causas de los defectos de producción en cada proceso (extrusión, impresión, laminado, corte y sellado) en conjunto con los jefes de área y/o supervisores de turno (exmaquinistas sénior).

- Establecimiento de acciones correctivas

Se determinaron las acciones correctivas para las causas de los constantes defectos que producían el incremento de los índices de scrap. Fueron necesarias acciones para las maquinarias, métodos, mano de obra, materiales, etc.

\section{- Plan de autocontrol en la producción}

Se determinó el listado de defectos que se pueden originar en cada proceso, y se procedió a capacitar a los colaboradores al respecto, de acuerdo a las áreas donde ellos se encontraban involucrados. Además, se determinó que la frecuencia de estas capacitaciones tendría que ser trimestral.

- Se elaboró, conjuntamente con el área de sistemas, el módulo de producto observado y se mejoró el módulo de devoluciones internas para que los colaboradores registren en el ERP de la empresa los kilos de la producción que se encuentre defectuosa. Esto sinceraba los porcentajes de scrap.

Se procederá a evaluar los reportes de la cantidad de scrap de cada proceso. El cálculo del porcentaje de scrap anual se realiza con la siguiente fórmula:

- Porcentaje de scrap anual 
Kg. de Scrap

$\overline{\text { (Kg. de proceso anual + Kg. scrap anual }+ \text { Kg. chancaca anual) }}$

Nota: Esta fórmula se replica en los demás procesos. La chancaca solo se considera para el proceso de extrusión, se omite para los otros procesos.

Las OP por proceso en el pretest y postest son presentadas a continuación en la Tabla 1.

A continuación, se enuncia la hipótesis de investigación:

"Mediante la generación del plan de autocontrol de la producción en cada proceso, se reducirán los índices de scrap generado."

La variable de esta hipótesis son los índices de scrap, cuyo indicador a analizar en los procesos involucrados en la empresa en estudio (extrusión, impresión, corte, laminado y sellado) es el porcentaje de scrap.

A continuación, se enuncian las hipótesis estadísticas válidas para los procesos de extrusión, impresión, corte, laminado y sellado:

$$
\begin{aligned}
& H_{0}: \boldsymbol{\pi}_{1}=\boldsymbol{\pi}_{2} \\
& H_{1}: \boldsymbol{\pi}_{1}>\boldsymbol{\pi}_{2} \\
& \text { a: } 0.05
\end{aligned}
$$

\section{RESULTADOS}

\section{Extrusión}

Los índices de scrap de extrusión son presentados a continuación en la Tabla 2.
La prueba de hipótesis utilizada fue la $Z$ de proporciones y fue realizada en $\mathrm{R}$. Se obtuvo el siguiente resultado:

Prueba de proporciones de 1 muestra con corrección de continuidad

Data: 348667 de 10277944, probabilidad nula 0.0343

X-cuadrado $=43901, \mathrm{gl}=1, p$-valor $=1.727 \mathrm{e}-11$

Hipótesis alternativa: $p$ verdadera es menor que 0.0343 Intervalo de confianza del 95\%: 0.00000000
0.03401686

Estimaciones de muestra: $p 0.03392381$

Con base en la obtención del $p$-valor 1.727e-11, se rechaza la $H_{0}$ y se acepta la $H_{1}$ que afirma que el porcentaje de scrap en el proceso de extrusión se ha reducido.

\section{Impresión}

Los índices de scrap de impresión son presentados a continuación en la Tabla 3.

La prueba de hipótesis utilizada fue la $Z$ de proporciones y fue realizada en $\mathrm{R}$. Se obtuvo el siguiente resultado:

Prueba de proporciones de 1 muestra con corrección de continuidad

Data: 229219 de 8201515 , probabilidad nula 0.0267

X-cuadrado $=491.79, \mathrm{gl}=1, p$-valor $=1$

Tabla 1. Cantidad de OP.

\begin{tabular}{|c|c|c|c|c|c|}
\hline \multirow{2}{*}{ Año } & Extrusión & Impresión & Corte & Laminado & Sellado \\
\cline { 2 - 6 } & No. de OP & No. de OP & No. de OP & No. de OP & No. de OP \\
\hline 2014 (pretest) & 3231 & 3182 & 1775 & 929 & 1704 \\
\hline 2019 (posttest) & 3380 & 3054 & 1689 & 771 & 3380 \\
\hline
\end{tabular}

Fuente: Elaboración propia.

Tabla 2. Índices de scrap de extrusión.

\begin{tabular}{|c|c|c|c|c|c|}
\hline Año & Kg. de proceso & Kg. scrap proceso & Chancaca & \% de scrap anual & N. $^{\circ}$ de OP \\
\hline 2014 (pretest) & 14360612.30 & 511085 & 21062.30 & $3.43 \%$ & 3231 \\
\hline 2019 (postest) & 9911682.92 & 348667.20 & 17594.20 & $3.39 \%$ & 3380 \\
\hline
\end{tabular}

Fuente: Elaboración propia. 
Hipótesis alternativa: $p$ verdadera es menor que 0.0267

Intervalo de confianza del 95\%: 0.00000000 0.02804326

Estimaciones de muestra: $p 0.02794837$

Con base en la obtención del p-valor 1 , se acepta la $H_{0}$.

\section{Laminado}

Los índices de scrap de laminado son presentados a continuación en la Tabla 4.

La prueba de hipótesis utilizada fue la $Z$ de proporciones y fue realizada en $\mathrm{R}$. Se obtuvo el siguiente resultado:

Prueba de proporciones de 1 muestra con corrección de continuidad

Data: 8768 de 2012448, probabilidad nula 0.0093

X-cuadrado $=5336.5, \mathrm{gl}=1, p$-valor $<2.2 \mathrm{e}-16$

Hipótesis alternativa: $p$ verdadera es menor que 0.0093

Intervalo de confianza del 95\%: 0.000000000 0.004434169

Estimaciones de muestra: $p 0.004356883$
Con base en la obtención del $p$-valor 2.2e-16, se rechaza la $H_{0}$ y se acepta la hipótesis $H_{1}$, que afirma que el porcentaje de scrap en el proceso de laminado se ha reducido.

\section{Corte}

Los índices de scrap de corte son presentados a continuación en la Tabla 5.

La prueba de hipótesis utilizada fue la $Z$ de proporciones y fue realizada en $\mathrm{R}$. Se obtuvo el siguiente resultado:

Prueba de proporciones de 1 muestra con corrección de continuidad

Data: 55757 de 3152633, probabilidad nula 0.0153

X- cuadrado $=1191, g l=1, p$-valor $=1$

Hipótesis alternativa: $p$ verdadera es menor que 0.0153

Intervalo de confianza del 95\%: 0.00000000 0.01780853

Estimaciones de muestra: $p 0.01768585$

Con base en base la obtención del $p$-valor 1 , se acepta la $H_{0}$.

\section{Sellado}

Los índices de scrap de sellado son presentados a continuación en la Tabla 6.

Tabla 3. Índices de scrap de impresión.

\begin{tabular}{|c|c|c|c|c|}
\hline Año & Kg. de proceso & Scrap proceso & \% de scrap anual & N. $^{\circ}$ de OP \\
\hline 2014 (pretest) & 11385732.43 & 312832.60 & $2.67 \%$ & 3.182 \\
\hline 2019 (postest) & 7972305.47 & 229209.72 & $2.79 \%$ & 3.054 \\
\hline
\end{tabular}

Fuente: Elaboración propia.

Tabla 4. Índices de scrap de laminado.

\begin{tabular}{|c|c|c|c|c|}
\hline Año & Kg. de proceso & Scrap proceso & \% de scrap anual & N. $^{\circ}$ de OP \\
\hline 2014 (pretest) & 2126579.89 & 19902.50 & $0.93 \%$ & 929 \\
\hline 2019 (postest) & 2003680.43 & 8767.52 & $0.44 \%$ & 771 \\
\hline
\end{tabular}

Fuente: Elaboración propia.

Tabla 5. Índices de scrap de corte.

\begin{tabular}{|c|c|c|c|c|}
\hline Año & Kg. de proceso & Scrap proceso & \% de scrap anual & N. $^{\circ}$ de OP \\
\hline 2014 (pretest) & 3765802.30 & 58440 & $1.53 \%$ & 1775 \\
\hline 2019 (postest) & 3096874.58 & 55757.31 & $1.77 \%$ & 1689 \\
\hline
\end{tabular}

Fuente: Elaboración propia. 
Tabla 6. Índices de scrap de sellado.

\begin{tabular}{|c|c|c|c|c|}
\hline Año & Kg. de proceso & Scrap proceso & \% de scrap anual & N. $^{\circ}$ de OP \\
\hline 2014 (pretest) & 7682209.69 & 221166.60 & $2.80 \%$ & 1704 \\
\hline 2019 (postest) & 5171234.00 & 97649.80 & $1.85 \%$ & 3380 \\
\hline
\end{tabular}

Fuente: Elaboración propia.

La prueba de hipótesis utilizada fue la $Z$ de proporciones y fue realizada en $\mathrm{R}$. Se obtuvo el siguiente resultado:

Prueba de proporciones de 1 muestra con corrección de continuidad

Data: 97649.8 de 5268884, probabilidad nula 0.028

X-cuadrado $=17349, \mathrm{gl}=1, p$-valor $<2.2 \mathrm{e}-16$

Hipótesis alternativa: $p$ verdadera es menor que 0.028

Intervalo de confianza del $95 \%$ : 0.00000000 0.01863029

Estimaciones de muestra: $p 0.0185333$

En base a la obtención del $p$-valor $2.2 \mathrm{e}-16$, se rechaza la $H_{0}$ y se acepta la hipótesis de $H_{1}$, que afirma que el porcentaje de scrap en el proceso de sellado se ha reducido.

\section{DISCUSIÓN}

Los índices de scrap generados durante el proceso de producción eran ocasionados por la falta de control de los mismos, en la mayoría de los casos, atribuible al factor humano. Por desconocimiento de los defectos durante la producción, se generaban considerables cantidades de producto intermedio con defectos. La elaboración de un plan de autocontrol de la producción en cada uno de los procesos permitió que los índices mensuales de scrap disminuyeran.

En los procesos de impresión y corte, no se observó una disminución de scrap debido a la alta rotación del personal en dichas áreas. Se deberá considerar disminuir la frecuencia de las capacitaciones y reforzar el proceso de inducción.

Los resultados obtenidos en cuanto a la hipótesis guardan similitud con los de las investigaciones de Cáceres (2017), Fernández y Ramírez (2017), puesto que presentan un plan de mejora, rediseño y optimización de procesos. En todos estos casos similares a la presente investigación, se comprueban las mejoras obtenidas en la implementación de dichos planes en sus respectivos escenarios.

\section{CONCLUSIONES}

1. Se concluye que en los procesos de extrusión, laminado y sellado se evidencia la disminución de scrap, mientras que en los procesos de impresión y corte dicha hipótesis es rechazada.

2. El proceso de impresión y corte no logró disminuir el scrap de proceso debido a la alta rotación del personal y falta de inducción adecuada al momento del ingreso a la empresa.

3. Se concluye que se debe realizar un análisis más profundo para reducir los porcentajes de scrap en los procesos de impresión y corte.

4. Los miembros del personal involucrado en la ejecución de los procesos mencionados fueron informados sobre la lista de defectos de cada uno de los procesos y capacitados de manera que puedan reconocerlos en el transcurso de los mismos.

5. La mejora continua de los procesos para la disminución de scrap sirvió para la optimización de tiempos, puesto que se eliminaron varios reprocesos innecesarios de producción defectuosa; asimismo, resultó en la disminución de costos.

6. Se elaboraron varios procedimientos durante la determinación de control de los procesos y de las fichas que el personal marca.

\section{REFERENCIAS BIBLIOGRÁFICAS}

[1] Alarcón, J. (1998). Reingeniería de procesos empresariales: teoría y práctica de la reingeniería de la empresa a través de su estrategia, sus procesos y sus valores corporativos. Madrid, España: Fundación Confemetal.

[2] Cáceres, A. (2017). Aplicación de la mejora continua y su efecto en la productividad de los procesos del almacén de una empresa comercializadora de productos electrónicos 
en Lima Metropolitana. (Tesis de maestría). Universidad Ricardo Palma, Lima.

[3] Chang, R. (1996). Mejora continua de procesos: Guía práctica para mejorar procesos y lograr resultados medibles ( $1^{\text {a }}$ ed.). Barcelona, España: Ediciones Granica.

[4] Chiavenato, I., y Sapiro, A. (2011). Planeación estratégica. Fundamentos y aplicaciones $\left(2^{\mathrm{a}}\right.$ ed.). México D.F., México: McGraw-Hill Education.

[5] D’Alessio, F. (2004). Administración y dirección de la producción. Naucalpan de Juárez, México: Pearson Educación.

[6] De Asís, M. (2007). Análisis de eficiencia de los departamentos universitarios. El caso de la universidad de Sevilla. Madrid, España: Editorial Dykinson S.L.

[7] Everett, A., y Ronald, E. (1991). Administración de la producción y operaciones. México: Prentice-Hall.

[8] Fernández, A., y Ramírez, L. (2017). Propuesta de un plan de mejoras, basado en gestión por procesos, para incrementar la productividad en la empresa distribuciones $A$ \& B. (Tesis de pregrado). Universidad Señor de Sipán, Pimentel.
[9] García, A. (1998). Conceptos de organización industrial. Barcelona, España: Marcombo S.A.

[10] Gutiérrez E., y Vega S. (2019). Plan de mejora para incrementar la productividad en el área de producción de la empresa JOSATEX. (Tesis de pregrado). Universidad Señor de Sipán, Pimentel.

[11] Hammer, M., y Champy, J. (1994). Reingeniería: Olvide lo que usted sabe sobre cómo debe funcionar una empresa: ¡Casi todo está errado! ( $1^{\mathrm{a}}$ ed.) Bogotá, Colombia: Norma.

[12] Lynch, R., y Cross, K. (1993) La mejora continua: Patrones y medidas, ( $1^{\mathrm{a}} \mathrm{ed}$.). Bilbao, España: Editorial Deusto.

[13] Martín, S., y Martín S, P. (2013). La excelencia operativa en la Administración Pública. Madrid, España: Instituto Nacional de Administración Pública.

[14] Pérez, J. (2010). Gestión por Procesos (4ª ed.). México: Alfaomega grupo editor, S.A. de C.V.

[15] Socconini, L. (2014). Lean Company: Más allá de la manufactura ( $1^{a}$ ed.). México D.F., México: Norma Ediciones. 


\section{Influence of the Redesign of the Production Processes of a Flexible Packaging Company Based on Continuous Improvement}

\begin{abstract}
The company under study aimed to reduce the scrap rates of each process of flexible packaging manufacturing, originated as a result of poor procedures, returned products, and observed spools and/or bales. A reduction in claims was also expected as a result of the improvement in the quality of the finished product. The reduction of scrap in each process of the plastics division led to a reduction in reprocessing and costs. This, in turn, had a positive impact on the company's income as the provision of high quality products resulted in customer loyalty. Furthermore, processes in the areas of extrusion, printing, cutting, laminating and sealing were made more efficient. The standardization of procedures and processes improved their execution time, creating a more positive image for customers and competitors.
\end{abstract}

Keywords: procedures; reprocessing; customer; claims.

\section{INTRODUCTION}

This research is intended to serve as a basis for cutting-edge, academic or socially useful research that will benefit:

- Researchers, students and people interested in the continuous improvement of processes, since the most relevant aspects are emphasized.

- Shareholders and collaborators of the company, since better profit margins are obtained.

- Customers, since a low rate of non-conforming products is observed.

- Competitors, since improvements are recommended to reduce scrap.

This article is intended to be an evaluation tool that provides understanding of the factors that influence the generation of scrap and its consequences, as well as the behavioral pattern of these factors. For all interested parties, this work is a research proposal to obtain efficient processes that generate low scrap rates.

This research also describes the redesign of the processes based on continuous improvement, via the evaluation and execution of:

- Production Self-Inspection Plan

- Root Cause Analysis (RCA) for non-conforming products

- Corrective actions

Moreover, it aims to identify how the scrap rates generated in the processes of the plastics production division can be reduced based on the development of a self-inspection plan for each process.

\section{BACKGROUND}

Fernández and Ramirez (2017) developed an improvement method for process management to increase productivity, very similar to the one developed in this paper.

1 Industrial engineer from Universidad Alas Peruanas. Currently working as an independent consultant. (Lima, Peru).

ORCID: https://orcid.org/0000-0002-0118-971X

Corresponding author: alizaldeamolina@gmail.com 
Cáceres (2017) observed that continuous improvement optimized the processes in an electronic products warehouse and, thus, increased its productivity.

Gutiérrez and Vega (2019) draw up an improvement plan in the production area to increase productivity and concluded that the standardization of procedures is essential for the development of an improvement plan.

\section{Efficiency}

According to De Asís (2007), efficiency implies the optimal use of resources to avoid wasting them. Based on this statement, the efficiency of a company, product or person depends on their ability to obtain optimal results while minimizing the economic impact of resources. Consequently, the company's manager must have a detailed understanding of the processes involved in the organization and must also implement strategic improvement

\section{Continuous Improvement}

Chang (1996) provides a methodical guide for significant improvements in the manufacturing processes that provide products and services to customers. Continuous improvement involves closely observing processes and finding ways to improve them. The aim is to obtain faster results, noticeable improvement and a more efficient or effective way to provide a service or product.
Continuous process improvement is the creation of methodologies (procedures, monitoring, performance measurements, etc.) that focus on the continuous examination of the problems that arise in the organization; it also aims to optimize the product or service provided by the organization, resulting in customer satisfaction, cost reduction and resource streamlining.

Figure 1 graphically illustrates the concept described in the preceding paragraph.

\section{Production}

According to D'Alessio (2004), production encompasses the planning, design, operation and control of the systems that produce goods and services. It also includes a wide range of production processes that add value to the product or service. Everett and Ronald (1991) state that production involves the transformation of inputs or raw materials into a product. The authors agree that production involves the development of goods or activities comprising a set of tangible or intangible functions to satisfy the customer. They also emphasize the interconnection of the phases of production required to obtain the good or service.

Production is the result of activities where a good or service is obtained and, to that end, each process carried out adds value.

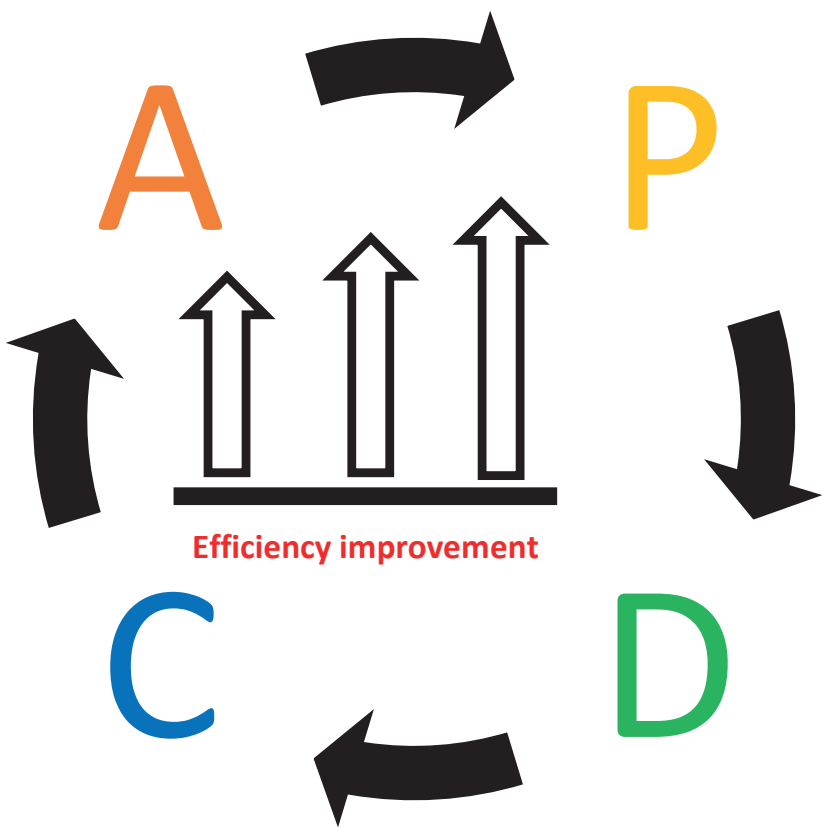

Figure 1. Continuous improvement scheme. Source: Prepared by the author. 


\section{Processes}

Martín and Martín (2013) state that processes are the set of activities that manage inputs and outputs. Mapping, defining and controlling the processes provides insight into the activities developed within the organization and, therefore, the opportunity to further implement continuous improvement. There are inputs and outputs in the process. Inputs are the supplies or raw materials relevant to the elaboration of the activities that make up the process; whereas the outputs are made up of the product and the wastes that are produced. Additionally, they reveal the importance of process control in the optimization of the organization's activities.

For García (1998), a process originates from a known initial situation intended to culminate in an also known situation, but a number of barriers or obstacles are encountered along the way, which must be addressed by performing specific operations. The author emphasizes that between the beginning and the end of the process, unforeseen events arise that must be examined and mitigated; all process activities must be identified and known, for only then will the necessary procedures for their inspection be determined, making it crucial for the analyst to be familiar with the processes involved.

According to Alarcón (1998), a process is a group of activities that, using inputs, creates a product of value for the customer. These activities are interrelated and end with the delivery of the product or service.

In the preceding paragraph it is stressed that the activities to obtain a product or service must be closely interconnected and related in order to provide the added value required at each stage of its production.

In turn, Chiavenato and Sapiro (2011) state that processes are the means by which results are obtained. They are sets of activities that use resources to transform materials or raw materials into products. It is worth noting that process management creates a dynamic of continuous improvement for organizations to obtain significant gains in terms of performance, efficiency, effectiveness and cost.

In the above statement, mention is made of the outputs or results of the sets of activities; inputs are used to obtain these results. Process management is also mentioned and how it is aimed at creating a culture of process optimization for better organizational productivity.

Similarly, Pérez (2010) states that a process is a set of interrelated activities that transform inputs into value-added outputs. The author also states that processes are orderly sequences of repetitive activities whose product has important values for customers. Figure 2 illustrates this concept.

Processes must have a sequence of tasks that interact in a specific fashion; furthermore, this set of tasks results in the execution of the activities necessary to obtain a final product that meets the requirements of the customer.

\section{Process Redesign}

Alarcón (1998) states that a basic and deep understanding of the processes that provide added value

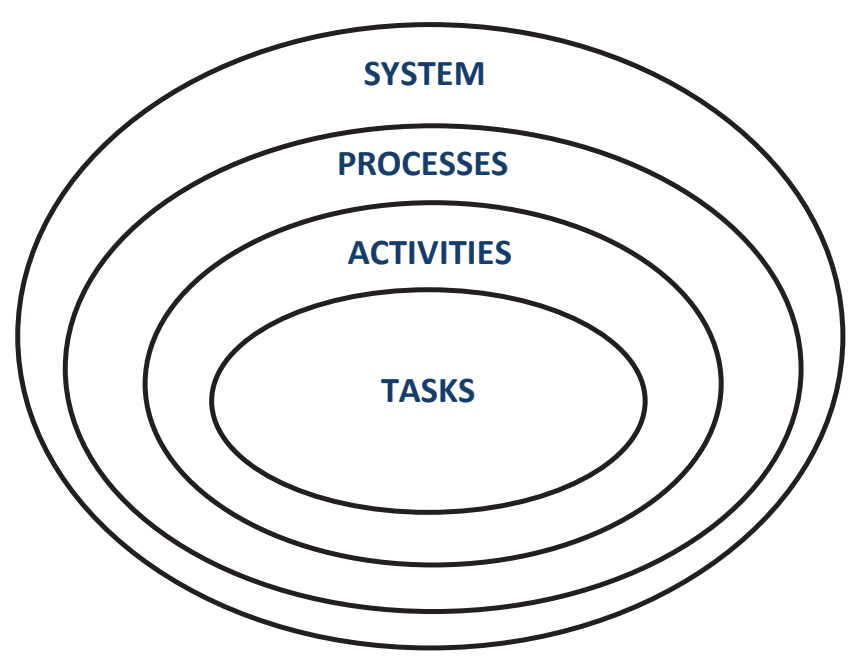

Figure 2. Set of system and processes. Source: Pérez (2010), Gestión por Procesos p. 52. 
in the eyes of customers is fundamental to completely redesign the processes and to significantly modify them in order to obtain drastic improvements in cost, quality, service, productivity, speed, etc. In addition, the purpose of the work and the structures of the company change at the same time, thus making it possible to determine the suitability of the implementation of new corporate strategies.

Process redesign can only be accomplished with a thorough understanding of all activities that are essential for production; such a change may, but need not necessarily, require a large investment, however, the long-term benefits are greater than the investment.

Process redesign is explained simply and graphically in Figure 3.

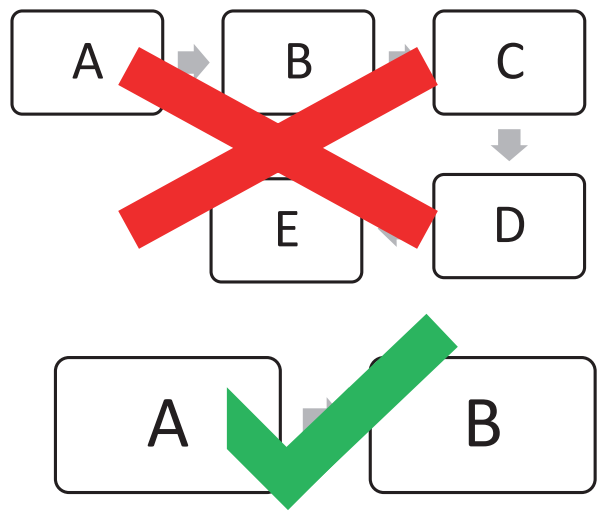

Figure 3. Definition of Process Redesign. Source: Prepared by the author.

\section{METHODOLOGY}

A time series quasi-experimental research design was used, as several observations were made on one or more variables at pre-test and post-test. The scheme used is presented below:

\section{$010203 \times 040506$}

Where:

O: are the observations made at pre-test and post-test.

$X:$ is the implementation of the independent variable.

A quantitative and experimental approach is used because data will be collected to test the hypothesis, relying on the measurement of variables and the manipulation of an independent variable.
The units of analysis will be the production orders (PO) of the company under study and the statistical reports obtained from the historical data, considering 2014 as pre-test and 2019 as post-test phases for each of the processes.

Process redesign based on continuous improvement was conducted via the evaluation and execution of:

- Root Cause Analysis (RCA) for nonconforming products

Causes of production defects in each process (extrusion, printing, laminating, cutting and sealing) were defined in conjunction with the area managers and/or shift supervisors (former senior machinists).

\section{- Corrective actions}

Corrective actions were designed to deal with the sources of the constant defects causing the increase in scrap rates. Corrective actions were needed for machinery, methods, labor, materials, etc.

\section{- Production Self-Inspection Plan}

A list of defects that may appear in each process was compiled, and the employees were trained according to their work areas. Also, it was decided that the frequency of trainings should be every three months.

Together with the systems area, the observed product module was developed and the internal returns module was improved in order to allow employees to register in the company's ERP the kilograms of defective production; thus, scrap percentages were accurately calculated.

Reports on the amount of scrap for each process were then analyzed. The annual scrap percentage was calculated using the following formula:

\section{- Annual scrap percentage}

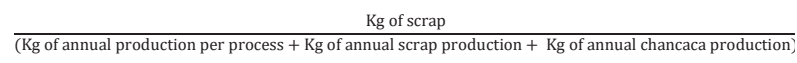

Note: The formula was also applied to the other processes. Chancaca ${ }^{2}$ was only considered for the extrusion process.

Table 1 shows the POs by process in the pre-test and post-test phases.

The research hypothesis is stated below:

2 Raw cane sugar typical of Central and Latin America, also known as panela. 
"Scrap rates will be reduced through the development of a production self-inspection plan for each process."

Scrap rates represent the variable of this hypothesis, where the indicator to be analyzed in the processes of the company under study (extrusion, printing, cutting, laminating and sealing) is scrap percentage.

The statistical hypotheses valid for the extrusion, printing, cutting, laminating and sealing processes are set out below:

$$
\begin{aligned}
& H_{0}: \boldsymbol{\pi}_{1}=\boldsymbol{\pi}_{2} \\
& H_{1}: \boldsymbol{\pi}_{1}>\boldsymbol{\pi}_{2} \\
& \text { a: } 0.05
\end{aligned}
$$

\section{RESULTS}

\section{Extrusion Process}

Extrusion scrap rates are presented below in Table 2.

A Z-test of proportions in $\mathrm{R}$ was used for the hypothesis testing. The following result was obtained:

\section{1-sample proportions test with continuity correction}

Data: 348667 de 10277944 , null probability 0.0343
X-squared $=43901, \mathrm{df}=1, p$-value $=1.727 \mathrm{e}-11$

Alternative hypothesis: true $p$ is less than 0.0343

95 percent confidence interval: 0.00000000 0.03401686

Sample estimates: $\quad p 0.03392381$

Based on the $p$-value of $1.727 \mathrm{e}-11$, the null hypothesis $H_{0}$ is rejected and $H_{1}$, that states that the scrap percentage from the extrusion process has been reduced is accepted.

\section{Printing Process}

Printing scrap rates are presented in Table 3.

A Z-test of proportions in $\mathrm{R}$ was used for the hypothesis testing. The following result was obtained:

1-sample proportions test with continuity correction

Data: 229219 de 8201515 , probability 0.0267

X-squared $=491.79, \mathrm{df}=1, p$-value $=1$

Alternative hypothesis: true $p$ is less than 0.0267

95 percent confidence interval: 0.00000000 0.02804326

Sample estimates: $\quad p 0.02794837$

Table 1. Number of POs.

\begin{tabular}{|c|c|c|c|c|c|}
\hline \multirow{2}{*}{ Year } & Extrusion & Printing & Cutting & Laminating & Sealing \\
\cline { 2 - 6 } & No. of POs & No. of POs & No. of POs & No. of POs & No. of POs \\
\hline 2014 (pre-test) & 3231 & 3182 & 1775 & 929 & 1704 \\
\hline 2019 (post-test) & 3380 & 3054 & 1689 & 771 & 3380 \\
\hline
\end{tabular}

Source: Prepared by the author.

Table 2. Extrusion Scrap Rates.

\begin{tabular}{|c|c|c|c|c|c|}
\hline Year & $\begin{array}{c}\text { Kg of production } \\
\text { per process }\end{array}$ & $\begin{array}{c}\text { Kg of scrap per } \\
\text { process }\end{array}$ & Chancaca & Annual scrap \% & No. of POs \\
\hline 2014 (pre-test) & 14360612.30 & 511085 & 21062.30 & $3.43 \%$ & 3231 \\
\hline 2019 (post-test) & 9911682.92 & 348667.20 & 17594.20 & $3.39 \%$ & 3380 \\
\hline
\end{tabular}

Source: Prepared by the author.

Table 3. Printing Scrap Rates.

\begin{tabular}{|c|c|c|c|c|}
\hline Year & Kg of production per process & Scrap per process & Annual scrap \% & No. of POs \\
\hline 2014 (pre-test) & 11385732.43 & 312832.60 & $2.67 \%$ & 3.182 \\
\hline 2019 (post-test) & 7972305.47 & 229209.72 & $2.79 \%$ & 3.054 \\
\hline
\end{tabular}

Source: Prepared by the author. 
Based on the $p$-value of 1 , then null hypothesis $H_{0}$ is accepted.

\section{Laminating Process}

Laminating scrap rates are presented in Table 4.

A Z-test of proportions in $\mathrm{R}$ was used for the hypothesis testing. The following result was obtained:

1-sample proportions test with continuity correction

Data: 8768 de 2012448, null probability 0.0093

X-squared $=5336.5, \mathrm{df}=1, p$-value $<2.2 \mathrm{e}-16$

Alternative hypothesis: true $p$ is less than 0.0093

95 percent confidence interval: 0.000000000 0.004434169

Sample estimates: $\quad p 0.004356883$

Based on the $p$-value of $2.2 \mathrm{e}-16$, the null hypothesis $H_{0}$ is rejected and $H_{1}$, that states that the scrap percentage from the laminating process has been reduced is accepted.

\section{Cutting Process}

Cuting scrap rates are presented in Table 5.

A Z-test of proportions in $\mathrm{R}$ was used for the hypothesis testing. The following result was obtained:

1-sample proportions test with continuity correction
Data: 55757 de 3152633, null probability 0.0153

X-squared $=1191, \mathrm{df}=1, p$-value $=1$

Alternative hypothesis: true $p$ is less than 0.0153

95 percent confidence interval: 0.00000000 0.01780853

Sample estimates: $\quad p 0.01768585$

Based on the $p$-value of 1 , then null hypothesis $H_{0}$ is accepted.

\section{Sealing Process}

Sealing scrap rates are presented in Table 6.

A Z-test of proportions in $\mathrm{R}$ was used for the hypothesis testing. The following result was obtained:

1-sample proportions test with continuity correction

Data: 97649.8 de 5268884, null probability 0.028

X-squared $=17349, \mathrm{df}=1, p$-value $<2.2 \mathrm{e}-16$

Alternative hypothesis: true $p$ is less than 0.028

95 percent confidence interval: 0.00000000 0.01863029

Sample estimates: $p 0.0185333$

Based on the $p$-value of $2.2 \mathrm{e}-16$, the null hypothesis $H_{0}$ is rejected and $H_{1}$, that states that the scrap

Table 4. Laminating Scrap Rates.

\begin{tabular}{|c|c|c|c|c|}
\hline Year & Kg of production per process & Scrap per process & Annual scrap \% & No. of POs \\
\hline 2014 (pre-test) & 2126579.89 & 19902.50 & $0.93 \%$ & 929 \\
\hline 2019 (post-test) & 2003680.43 & 8767.52 & $0.44 \%$ & 771 \\
\hline
\end{tabular}

Source: Prepared by the author.

Table 5. Cutting Scrap Rates.

\begin{tabular}{|c|c|c|c|c|}
\hline Year & Kg of production per process & Scrap per process & Annual scrap \% & No. of POs \\
\hline 2014 (pre-test) & 3765802.30 & 58440 & $1.53 \%$ & 1775 \\
\hline 2019 (post-test) & 3096874.58 & 55757.31 & $1.77 \%$ & 1689 \\
\hline
\end{tabular}

Source: Prepared by the author.

Table 6. Sealing Scrap Rates.

\begin{tabular}{|c|c|c|c|c|}
\hline Year & Kg of production per process & Scrap per process & Annual scrap \% & No. of POs \\
\hline 2014 (pre-test) & 7682209.69 & 221166.60 & $2.80 \%$ & 1704 \\
\hline 2019 (post-test) & 5171234.00 & 97649.80 & $1.85 \%$ & 3380 \\
\hline
\end{tabular}

Source: Prepared by the author. 
percentage from the sealing process has been reduced is accepted.

\section{DISCUSSION}

The scrap rates generated during the production process were due to the lack of control, in most cases human-caused. The lack of awareness of defects during production resulted in a considerable amount of intermediate product with defects. The development of a production self-inspection plan for each of the processes reduced the monthly scrap rates.

No scrap reduction was observed in the printing and cutting processes due to the high turnover of personnel in these areas. The company should consider reducing the frequency of training and reinforcing the induction process.

In terms of the hypothesis, the results obtained are similar to those obtained by Cáceres (2017), and Fernández and Ramírez (2017), as they propose a plan for improvement, redesign and optimization of processes. The improvements obtained in the implementation of these plans in their respective scenarios are verified in all the mentioned cases.

\section{CONCLUSIONS}

1. A decrease in scrap is evidenced in the extrusion, laminating and sealing processes, whereas in the printing and cutting processes this hypothesis is rejected.

2. The printing and cutting process failed to reduce process scrap due to the high personnel turnover and lack of adequate induction upon joining the company.

3. A comprehensive analysis should be carried out to reduce the scrap percentages in the printing and cutting processes.

4. Staff members involved in the execution of the mentioned processes were briefed on the list of defects for each of the processes and trained to recognize them in the course of the processes.

5. The continuous improvement of the processes for the reduction of scrap allowed time optimization, as several unnecessary reprocesses of defective production were eliminated; it also resulted in cost reduction.
6. Several procedures were developed during the determination of process control and control sheets.

\section{REFERENCES}

[1] Alarcón, J. (1998). Reingeniería de procesos empresariales: teoría y práctica de la reingeniería de la empresa a través de su estrategia, sus procesos y sus valores corporativos. Madrid, Spain: Fundación Confemetal.

[2] Cáceres, A. (2017). Aplicación de la mejora continua y su efecto en la productividad de los procesos del almacén de una empresa comercializadora de productos electrónicos en Lima Metropolitana. (Master thesis). Universidad Ricardo Palma, Lima.

[3] Chang, R. (1996). Mejora continua de procesos: Guía práctica para mejorar procesos y lograr resultados medibles ( $1^{\text {st }}$ ed.). Barcelona, Spain: Ediciones Granica.

[4] Chiavenato, I., \& Sapiro, A. (2011). Planeación estratégica. Fundamentos y aplicaciones $\left(2^{\text {nd }}\right.$ ed.). México D.F., Mexico: McGraw-Hill Education.

[5] D’Alessio, F. (2004). Administración y dirección de la producción. Naucalpan de Juárez, Mexico: Pearson Educación.

[6] De Asís, M. (2007). Análisis de eficiencia de los departamentos universitarios. El caso de la universidad de Sevilla. Madrid, Spain: Editorial Dykinson S.L.

[7] Everett, A., \& Ronald, E. (1991). Administración de la producción y operaciones. Mexico: Prentice-Hall.

[8] Fernández, A., \& Ramírez, L. (2017). Propuesta de un plan de mejoras, basado en gestión por procesos, para incrementar la productividad en la empresa distribuciones A \& $B$. (Undergraduate thesis). Universidad Señor de Sipán, Pimentel.

[9] García, A. (1998). Conceptos de organización industrial. Barcelona, Spain: Marcombo S.A.

[10] Gutiérrez E., \& Vega S. (2019). Plan de mejora para incrementar la productividad en el área de producción de la empresa JOSATEX. (Undergraduate thesis). Universidad Señor de Sipán, Pimentel.

[11] Hammer, M., \& Champy, J. (1994). Reingeniería: Olvide lo que usted sabe sobre 
cómo debe funcionar una empresa: ¡Casi todo está errado! ( $1^{\text {st }}$ ed.) Bogotá, Colombia: Norma.

[12] Lynch, R., \& Cross, K. (1993) La mejora continua: Patrones y medidas, $\left(1^{\text {st }}\right.$ ed.). Bilbao, Spain: Editorial Deusto.

[13] Martín, S., \& Martín S, P. (2013). La excelencia operativa en la Administración Pública. Madrid, Spain: Instituto Nacional de Administración Pública.
[14] Pérez, J. (2010). Gestión por Procesos (4 ${ }^{\text {th }}$ ed.). Mexico: Alfaomega grupo editor, S.A. de C.V.

[15] Socconini, L. (2014). Lean Company: Más allá de la manufactura ( $1^{\text {st }}$ ed.). México D.F., Mexico: Norma Ediciones. 